DUNDEE MEETING OF THE BRITISH ASSOCIATION, AUGUST 27SEPTEMBER 3

$\mathrm{A}^{\mathrm{s}}$ S has already been announced, the British Association will meet at Dundee during August 27-September 3, and a preliminary programme referring to general features of the meeting has been issued. The following notes, from the recorders of the various sections, amplify the information given there.

Section A (Mathematics and Physics). In his presidential address, Sir Edward Appleton will deal with the way in which radio has been used in com. munication and also as a method for investigating natural phenomena, by study of the reflexions from meteors and the reception of radio 'noise' from the sun and Milky Way. The session on September 2, devoted to "Coal as a Source of Heat and Power", will hear Sir Charles Ellis, who will be followed by contributors from the Fuel and the Building Research Stations on the efficient use of fuel and domestic heating systems. Prof. J. D. Bernal will review the question of coal economy, and Prof. D. M. Newitt will speak about the use of oxygen in carbonization processes and the storage of gases in liquid form. The British Coal Utilisation Research Association will deal with the combustion of coal in fuel beds. The discussion of modern methods of computation will include a general survey and a description of some large American machines.

Section E (Geography) will devote a whole day to a discussion of Scottish problems from the geographer's point of view. The National Atlas and urban geography will each have a morning. There will be an exhibition of maps produced by the Scottish Department of Health and the Ministry of Town and Country Planning.

Section $F$ (Economics). Current economic difficulties will receive particular attention. The presidential address is to be on the "Conditions of the Economic Outlook", and there will be papers on "The Significance of the New Issue Market for the Finance of Industry", "Land Compensation", "Social Accounting", "Profit and Enterprise", "Proposed Code of Industrial Management". A joint meeting with Section J (Psychology) will consider "Incentives in Industry".

Section $G$ (Engineering). An outstanding feature will be a series of short papers by junior engineers : thirty minutes is allotted to each speaker for his paper and the ensuing discussion. In preparation for the afternoon visits, the last item of the morning programme will be a summary of what is to be seen.

Section $H$ (Anthropology) will hold a symposium on problems of "Culture Change", to which members of the staff of the London School of Economics will contribute. The archæological side will discuss Pleistocene chronology under the title "Dating the Past". Papers are to be presented on a variety of subjects, including the technique of excavation, the education of the totally deaf child, the organisation of folk-life studies, reconstruction in the Naga Hills, and recent discoveries of fossil Hominoidea in South Africa.

Section I (Physiology) will hold a joint meeting with Sections $H$ and $J$ to discuss "Man and the Machine", with the object of showing how the physiology, anatomy and psychology of the man should be considered in the design of the machine he is to use. Two other meetings include Section J, when "Aviation Physiology" and "Climate and Health" will be discussed. On August 29 Sir Alexander Fleming will open a symposium with Sections B and $\mathrm{K}$ on "Penicillin and other Antibiotics". The use of tracer elements will be the subject of a meeting with Section B on the morning of September 2 . During the meeting a Children's Lecture on "Colour" will be given by Prof. H. H. Hartridge.

Section $J$ (Psychology). The contributions are mainly of practical interest, industrial and educational applications being especially prominent. The Section joins with others in discussing "Man and the Machine", "Allocation to Secondary Education" and "Incentives in Industry". The sectional meetings include symposia on "Selection for Management", "Public Opinion Surveys", "Rehabilitation of an Industrially Depressed Area", "Changes in Abilities with Age" and "The Scientific Study of National Character". Dr. S. J. F. Philpott's presidential address is 'Man's Adaptability".

Section $L$ (Education). Miss Grier's presidential address will be on the evolution of secondary education. Miss Lambert will present a paper on the "Problems of Selection Technique at the age of Transfer to Secondary Schools". There will be a discussion on adult education in the Services.

Section $M$ (Agriculture). The first session will be a joint one with Sections $B$ and $D$ to discuss insecticides. Papers will be presented (by Drs. H. G. Thornton, M. C. Rayner and A. P. Evans) on three aspects of soil biology-the roles of bacteria, mycorrhizas and earthworms in the economy of the soils and the maintenance of fertility. A session is devoted to recent advances in the control of animal diseases, and at the final session the Right Hon. Walter Elliott, M.P., Sir Jack Drummond and Mr. H. D. Walston will discuss, from the points of view of the agriculturist, nutritionist and economist, respectively, the vitally topical problem: How far could and should Britain feed herself? In his presidential address, Dr. W. G. Ogg will speak on "Soil and Health", and will describe recent studies on the effect of soil conditions on the health of plants and animals.

\section{METALLURGICAL PROBLEMS INVOLVED IN THE GENERATION OF USEFUL POWER FROM ATOMIC ENERGY*}

$\mathrm{T}$ HE design of even the simplest atomic energy reactor, the water-cooled carbon pile using natural uranium, presents many awkward technical problems. Metallic uranium has properties which make it a difficult material to work with. It melts at about $1,150^{\circ} \mathrm{C}$.; but below this temperature it undergoes two transitions, with unusually large volume changes. It is very reactive chemically, and readily attacked by water. For these reasons, and to retain the radioactive fission products, the uranium rods in a pile have to be enclosed in gas-tight sheaths, of materials which are good heat conductors, noncorrosive and do not absorb neutrons appreciably.

Substance of the May Lecture before the Institute of Metals delivered by Sir Wallace Akers, C.B.E., on May 21. 